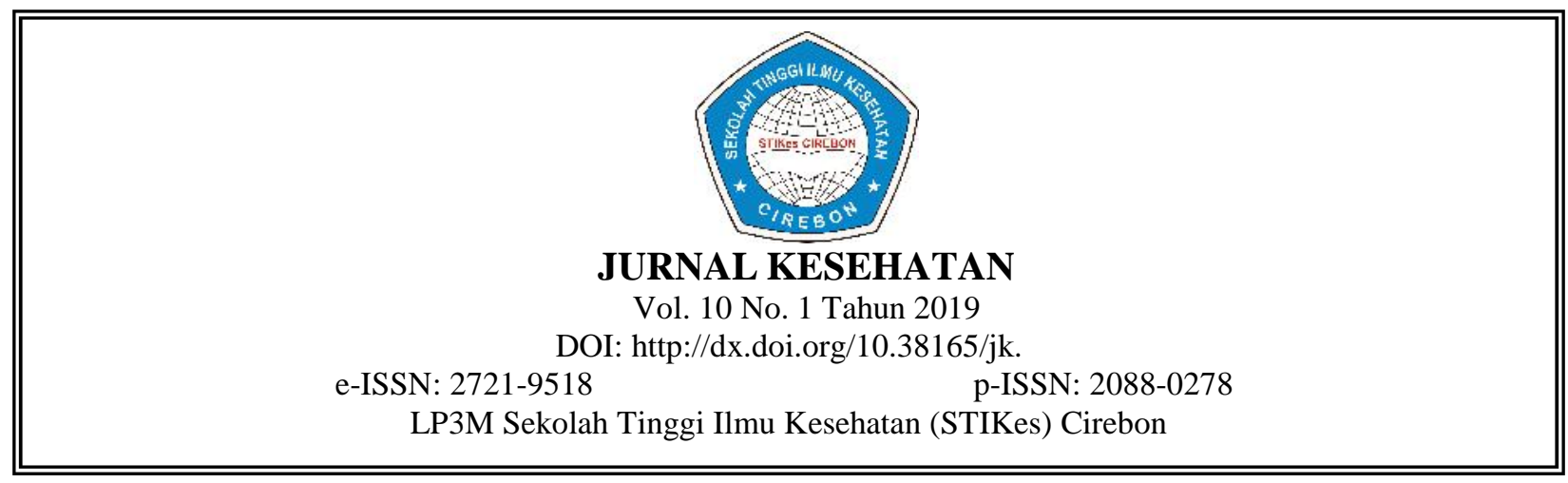

\title{
FAKTOR-FAKTOR YANG BERHUBUNGAN DENGAN KEAKTIFAN KADER POSYANDU
}

\author{
Herlinawati* \\ Program Studi Kesehatan Masyarakat Sekolah Tinggi Ilmu Kesehatan Cirebon \\ herlina56@gmail.com \\ Pujiati** \\ Program Studi Kesehatan Masyarakat Sekolah Tinggi Ilmu Kesehatan Cirebon
}

\begin{abstract}
Abstrak
Kader posyandu adalah wanita yang di pilih oleh masyarakat dan dilatih untuk menangani masalah- masalah kesehatan perorangan maupun masyarakat untuk bekerja dalam hubungan yang amat dekat dengan tempat-tempat pemberian pelayanan kesehatan. Keaktifan kader posyandu yang berada di wilayah kerja puskesmas kejaksan telah mencapai $75 \%$ yang aktif. Penelitian ini bertujuan untuk mengetahui faktor- faktor yang berkaitan dengan keaktifan kader posyandu seperti umur, pendidikan, pekerjaan dan pengetahuan. Metode yang digunakan pada penelitian ini adalah deskriptif analitik dengan menggunakan desain penelitian cross sectional. Pengumpulan data dilakukan dengan wawancara dan observasi menggunakan kuersioner dari populasi 117 kader di Wilayah Kerja Puskesmas Kejaksan Kota Cirebon dengan sampel sebanyak 53 kader yang dipilih berdasarkan metode proportional random sampling dan simple random sampling. Uji analisis untuk melihat hubungan variabel bebas dan terikat dengan uji Chi-Square. Data penelitian diolah secara kuantitatif dengan menggunakan SPSS. Hasil penelitian menunjukkan bahwa tidak ada hubungan secara statistik antara keaktifan kader di wilayah kerja Puskesmas Kejaksan Kota Cirebon menurut umur, pekerjaan, dan pendidikan serta ada hubungan antara keaktifan kader posyandu di wilayah kerja Puskesmas Kejaksan Kota Cirebon dengan pengetahuan.
\end{abstract}

Kata Kunci: Pendidikan, pekerjaan, keaktifan kader

\begin{abstract}
Posyandu Cadre is selected by the community and trained to deal with problems of health of individuals or communities to work in a relationship that is very close to the places where the granting of health services.Posyandu cadre of liveliness in the workplace clinics kejaksan has reached 75\%.This research aims to know the factors relating to the liveliness of the posyandu cadre such as age, education, work and knowledge. The methods used in this research is descriptive analytic with cross sectional design research use.Data collection was done with interviews and observations using the kuersioner of the population 117 cadres in the region the city of Cirebon Kejaksan Clinics with samples as much as 53 cadres who are selected based on the method of proportional random sampling and simple random sampling.Test analysis to see the free and bound variables relationship with Chi-Square test.Research data was processed using SPSS quantitatively. The results of this study found the lack of relationship statistically between the liveliness of the cadres in the region the city of Cirebon Kejaksan Clinics according to age, occupation, and education as well as there is a connection between the liveliness of the cadres of posyandu in working area Clinics The city of Cirebon Kejaksan with knowledge. Recommended for health services required the presence of supervision and posyandu cadre training, especially holders of the program and related institutions to improve the posyandu directly, and to conduct training and coaching clinics on a regular basis regarding posyandu, basic tasks and functions of posyandu cadre that is in focus to low-educated cadres and cadres.
\end{abstract}

Keywords: Education, work, activeness of cadres 


\section{PENDAHULUAN}

Posyandu merupakan salah satu bentuk UKBM yang dikelola dan diselenggarakan dari, oleh, untuk, dan bersama masyarakat dalam penyelenggaraan pembangunan kesehatan, guna memberdayakan masyarakat dan memberikan kemudahan kepada masyarakat dalam memperoleh pelayanan kesehatan dasar, utamanya untuk mempercepat penurunan angka kematian ibu dan bayi. Oleh sebab itu, untuk mendukung pembinaan posyandu di perlukan langkah-langkah edukasi kepada masyarakat antara lain dengan upaya peningkatan kapasitas kader melalui pelatihan kader posyandu. $^{1}$

Posyandu tersebar lebih dari 70.000 desa di Indonesia. Pada tahun 2010, diperkirakan sekitar 91,3\% anak 6-11 bulan dan 74,5\% balita dibawa ke posyandu sekurang-kurangnya satu kali selama enam bulan terakhir. ${ }^{2}$ Posyandu yang tersebar di Jawa Barat pada tahun 2011 mencapaai 50.541 dan sekitar 49.649 posyandu yang aktif dengan strata 45,83\% madya, 30,54\% pratama dan sebanyak 24,63\% mandiri. Sedangkan untuk wilayah Kota Cirebon jumlah posyandu pada tahun 2018 ada 330 posyandu, bertambah 1 posyandu di bandingkan tahun sebelumnya termasuk diantaranya sebanyak 16 unit Posyandu berada di wilayah Kerja Puskesmas Kejaksan Kota Cirebon dan memiliki $47,7 \%$ posyandu dengan strata purnama. ${ }^{3}$

Berdasarkan surat edaran menteri dalam negeri dan otonomi daerah Nomor:411.3/1116/SJ tanggal 13 juni 2001, yang merupakan pedoman Bupati/Walikota di Indonesia tentang revitalisasi posyandu. Di mana diharapkan akan mengembalikan kerja posyandu dan keaktifan-keaktifan kader didalamnya. $^{4}$

Kader posyandu adalah wanita yang dipilih oleh masyarakat dan dilatih untuk menangani masalah-masalah kesehatan perseorangan maupun masyarakat untuk bekerja dalam hubungan yang amat dekat dengan tempat-tempat pemberian pelayanan kesehatan. Tim pembinaan kader melibatkan dari beberapa sektor. Camat otomatis ikut bertanggung jawab terhadap pelatihan namun secara teknis oleh petugas puskesmas. Pelaksanaan harian pembinaan ini adalah staf puskesmas. Para kader posyandu membutuhkan pembinaan atau pelatihan dalam rangka menghadapi tugastugas mereka. ${ }^{4}$

Upaya untuk memasyarakatkan program posyandu di era pemerintahan orde baru cukup gencar dikampanyekan ke masyarakat dengan slogan "Ayo ke posyandu", namun di Era Reformasi berlangsung perkembangan posyandu kelihatannya mengalami kemunduran, karena terkesan pembangunan politik dan ekonomi lebih diprioritaskan dari pada pembangunan sosial, akibatnya pembangunan kesehatan yang berbasis masyarakat sedikit terabaikan, sehingga dampaknya terhadap keberadaan posyandu seolah-olah menjadi "Hidup segan mati tak mau". Salah satu fakta di lapangan dapat kita lihat yaitu adanya kader yang bertugas kurang aktif dan jumlahnya tidak lengkap. ${ }^{5}$ Mengingat begitu strategisnya keberadaan kader maka untuk lebih optimalnya dalam memberikan pelayanan, pemerintah memprogramkan pemberian pelatihan kader. ${ }^{6}$

Puskesmas Kejaksan Kota Cirebon merupakan salah satu unit pelaksana teknis Dinas Kesehatan Kota Cirebon yang berada di wilayah kecamatan Kejaksan yang mempunyai tugas pokok melaksanakan kegiatan bidang upaya kesehatan pokok yang meliputi pelayanan promosi kesehatan, gizi, penyehatan lingkungan, pencegahan dan pemberantasan penyakit, kesehatan ibu dan anak, dan pelayanan kesehatan serta program Upaya Kesehatan Berbasis Masyarakat seperti posyandu. Posyandu yang berada di wilayah kerja Puskesmas Kejaksan sampai tahun 2018 ada 16 unit posyandu dengan 4 unit posyandu strata mandiri, 4 unit strata madya dan 8 unit strata purnama.

Berdasarkan data keaktifan kader posyandu yang berada di wilayah kerja Puskesmas Kejaksan pada tahun 2018 diatas diketahui total jumlah kader sebanyak 117 orang yang tersebar di 16 posyandu di wilayah kerja Puskesmas Kejaksan Kota Cirebon dan ada 44 orang kader yang tidak aktif.

Menurut Depkes RI menunjukkan masih ada posyandu yang mengalami keterbatasan kader, yaitu tidak semua kader aktif dalam setiap kegiatan posyandu sehingga pelayanan tidak berjalan lancar. Keterbatasan kader disebabkan adanya kader drop out karena lebih tertarik bekerja ditempat lain yang memberikan keuntungan ekonomis, kader pindah karena ikut suami, dan juga setelah 
bersuami tidak mau lagi menjadi kader, kader sebagai relawan merasa jenuh dan faktor-faktor lainnya seperti kurangnya pelatihan serta adanya keterbatasan pengetahuan dan pendidikan yang seharusnya dimilikioleh seorang kader, karena berdasarkan penelitian sebelumnya kader yang direkrut oleh staf puskesmas kebanyakan hanya berpendidikan sampai tingkat SLTA dengan pengetahuan yang sangat minim dan umumnya tidak bekerja.

Penelitian Nur Farida Yohanik yang meneliti tentang faktor-faktor yang berhubungan dengan keaktifan kader dalam pengelolaan desa siaga aktif di Puskesmas Tanjunganom jawa timur diketahui bahwa variabel umur, jenis kelamin, pendidikan, pekerjaan dan pengetahuan berhubungan dengan keaktifan kader posyandu, sedangkan Penelitian Dani Akmalina tentang faktor-faktor yang berhubungan dengan keaktifan kader posyandu di wilayah kerja Puskesmas Nelayan tahun 2013 didapatkan bahwa variabel umur, pendidikan, pekerjaan dan pengetahuan berhubungan dengan keaktifan kader posyandu. ${ }^{7}$ Penelitian ini bertujuan untuk mengetahui faktor-faktor yang mempengaruhi keaktifan kader posyandu di wilayah Kerja UPT Puskesmas Kejaksan Kota Cirebon.

\section{METODE PENELITIAN}

Rancangan penelitian yang digunakan adalah penelitian deskriptif analitik yaitu penelitian untuk menjelaskan hubungan antara variabel terikat dan variabel bebas melalui pengujian hipotesis. Metode yang digunakan adalah metode survey dan pendekatan yang digunakan adalah pendekatan cross sectional. Variabel bebas dalam penelitian ini adalah umur, pendidikan, pekerjaan, dan pengeahuan.Sedangkan variabel terikat dalam penelitian ini adalah keaktifan kader posyandu.

Populasi dalam penelitian ini adalah semua Kader Posyandu yang terdaftar di wilayah Kerja Puskesmas Kejaksan adalah sebanyak 117 orang. Jumlah sampel sebanyak 53 kader. Teknik pengambilan sampel menggunakan teknik propotional random sampling.

Instrumen yang digunakan dalam penelitian ini adalah kuesioner, metode pengumpulan data dengan wawancara kepada responden sedangkan data sekunder untuk mengetahui keaktifan kader di posyandu diambil dengan cara studi dokumentasi (data puskesmas). Analisis data menggunakan analisis univariat untuk mendeskripsikan masing-masing variabel dengan menggunakan distribusi frekuensi sedangkan analisis bivariat untuk mengetahui hubungan antara variabel independen dengan variabel dependen. Uji statistik yang digunakan adalah chi-square.

\section{HASIL PENELITIAN \\ Keaktifan Kader Posyandu}

Hasil penelitian menunjukkan bahwa kader yang aktif sebanyak 24 responden $(45,3 \%)$ sedangkan yang tidak aktif sebanyak 29 responden $(54,7 \%)$.

\section{Umur}

Hasil penelitian menunjukkan bahwa umur kader yang termasuk dalam kategori tua sebanyak 49 responden $(92,5 \%)$ sedangkan kategori muda sebanyak 4 responden $(7,5 \%)$.

\section{Pendidikan}

Hasil penelitian menunjukkan bahwa kader yang berpendidikan rendah sebanyak 27 responden $(50,9 \%)$ sedangkan yang berpendidikan tinggi sebanyak 26 responden $(49,1 \%)$.

\section{Pekerjaan}

Hasil penelitian menunjukkan bahwa kader yang mempunyai pekerjaan sebanyak 1 responden $(1,9 \%)$ sedangkan yang tidak mempunyai sebanyak 52 responden $(98,1 \%)$. 


\section{Pengetahuan}

Hasil penelitian menunjukkan bahwa kader yang mempunyai pengetahuan rendah sebanyak 24 responden $(45,3 \%)$ sedangkan yang mempunyai pengetahuan tinggi sebanyak 29 responden $(54,7 \%)$.

\section{Hubungan umur dengan keaktifan kader posyandu}

Tabel 1. Hubungan Umur Dengan Keaktifan Kader Posyandu

\begin{tabular}{|c|c|c|c|c|c|c|c|}
\hline \multirow{3}{*}{ Umur } & \multicolumn{4}{|c|}{ Keaktifan Kader Posyandu } & \multirow{2}{*}{\multicolumn{2}{|c|}{ Jumlah }} & \multirow{3}{*}{$\mathrm{P}$ value } \\
\hline & \multicolumn{2}{|c|}{ Aktif } & \multicolumn{2}{|c|}{ Tidak Aktif } & & & \\
\hline & $\mathrm{N}$ & $\%$ & $\mathrm{~N}$ & $\%$ & $\mathrm{~N}$ & $\%$ & \\
\hline Tua & 21 & 42,9 & 28 & 57,1 & 49 & 100 & 0,472 \\
\hline Muda & 3 & 75,0 & 1 & 25,0 & 4 & 100 & \\
\hline Jumlah & 24 & 45,3 & 29 & 54,7 & 53 & 100 & \\
\hline
\end{tabular}

Berdasarkan pada tabel 1 Hasil analisis hubungan antara umur dengan keaktifan kader posyandu diperoleh bahwa ada sebanyak $21(42,9 \%)$ kader yang berumur tua menjadi kader yang aktif. Sedangkan kader yang berumur muda terdapat $3(75,0 \%)$ yang aktif. Dari hasil statistik di peroleh nilai $\mathrm{p}=0,472(\mathrm{p}>0,05)$ maka dapat disimpulkan bahwa tidak ada hubungan antara umur dengan keaktifan kader posyandu di wilayah kerja UPT Puskesmas Kejaksan Tahun 2019.

\section{Hubungan Pekerjaan dengan keaktifan kader posyandu}

Tabel 2. Hubungan Pekerjaan Dengan Keaktifan Kader Posyandu

\begin{tabular}{cccccccc}
\hline Pekerjaan & \multicolumn{3}{c}{ Keaktifan kader Posyandu } & \multicolumn{2}{c}{ Jumlah } & P value \\
\hline & \multicolumn{2}{c}{ Aktif } & \multicolumn{2}{c}{ Tidak Aktif } & & & \\
\hline & $\mathrm{N}$ & $\%$ & $\mathrm{~N}$ & $\%$ & $\mathrm{~N}$ & $\%$ & \\
\hline Bekerja & 0 & 0 & 1 & 100 & 1 & 100 & 1,000 \\
Tidak Bekerja & 24 & 46,2 & 28 & 53,8 & 52 & 100 & \\
\hline Jumlah & 24 & 45,3 & 29 & 54,7 & 53 & 100 & \\
\hline
\end{tabular}

Berdasarkan pada tabel 2 Hasil analisis hubungan antara pekerjaan dengan keaktifan kader posyandu diperoleh bahwa ada sebanyak $24(46,2 \%)$ kader tidak bekerja yang aktif dalam posyandu. Sedangkan kader yang bekerja tidak ada $0(0,0 \%)$ yang aktif. Dari hasil statistik di peroleh $\mathrm{p}=1,000(\mathrm{p}>0,05)$ yang menunjukkan $\mathrm{Ha}=$ ditolak, artinya tidak ada hubungan antara pekerjaan dengan keaktifan kader posyandu di wilayah kerja UPT Puskesmas Kejaksan Tahun 2019.

\section{Hubungan Pendidikan dengan keaktifan kader posyandu}

Tabel 3. Hubungan Pendidikan Dengan Keaktifan Kader Posyandu

\begin{tabular}{cccccccc}
\hline \multirow{2}{*}{ Pendidikan } & \multicolumn{3}{c}{ Keaktifan kader Posyandu } & & \multirow{2}{*}{ Jumlah } & \multirow{2}{*}{ Pvalue } \\
\cline { 2 - 6 } & \multicolumn{2}{c}{ Aktif } & \multicolumn{2}{c}{ Tidak Aktif } & & \\
\cline { 2 - 6 } & $\mathrm{N}$ & $\%$ & $\mathrm{~N}$ & $\%$ & $\mathrm{~N}$ & $\%$ & \\
\hline Rendah & 9 & 33,3 & 18 & 66,7 & 27 & 100 & \multirow{2}{*}{0,132} \\
Tinggi & 15 & 57,7 & 11 & 42,3 & 26 & 100 & \\
\hline Jumlah & 24 & 45,3 & 29 & 54,7 & 53 & 100 & \\
\hline
\end{tabular}

Berdasarkan pada tabel 3 Hasil analisis hubungan antara pendidikan dengan keaktifan kader posyandu diperoleh bahwa ada sebanyak $18(66,7 \%)$ kader yang pendidikannya rendah menjadi kader yang tidak aktif. Sedangkan yang pendidikan tinggi terdapat $11(42,3 \%)$ yang tidak aktif. Dari hasil statistik di peroleh $\mathrm{p}=0,132(\mathrm{p}>0,05)$ yang menunjukkan $\mathrm{Ha}=$ ditolak, artinya tidak ada 
hubungan antara pendidikan dengan keaktifan kader posyandu di wilayah kerja UPT Puskesmas Kejaksan Tahun 2019.

\section{Hubungan Pengetahuan dengan keaktifan kader posyandu}

Tabel 4 Hubungan Pengetahuan Dengan Keaktifan Kader Posyandu

\begin{tabular}{|c|c|c|c|c|c|c|c|}
\hline \multirow{3}{*}{ Pengetahuan } & \multicolumn{4}{|c|}{ Keaktifan kader Posyandu } & \multirow{2}{*}{\multicolumn{2}{|c|}{ Jumlah }} & \multirow{3}{*}{ Pvalue } \\
\hline & \multicolumn{2}{|c|}{ Aktif } & \multicolumn{2}{|c|}{ Tidak Aktif } & & & \\
\hline & $\mathrm{N}$ & $\%$ & $\mathrm{~N}$ & $\%$ & $\mathrm{~N}$ & $\%$ & \\
\hline Rendah & 3 & 12,5 & 21 & 87,5 & 24 & 100 & \multirow{3}{*}{0,000} \\
\hline Tinggi & 21 & 72,4 & 8 & 27,6 & 29 & 100 & \\
\hline Jumlah & 24 & 45,3 & 29 & 54,7 & 53 & 100 & \\
\hline
\end{tabular}

Berdasarkan pada tabel 4 Hasil analisis hubungan antara pengetahuan dengan keaktifan kader posyandu diperoleh bahwa ada sebanyak 3 (12,5\%) kader yang memiliki pengetahuan rendah menjadi kader yang aktif. Sedangkan kader yang memiliki pengetahuan tinggi terdapat $21(72,4 \%)$ yang aktif. Dari hasil statistik di peroleh $\mathrm{p}=0,000(\mathrm{p}<0,05)$ yang menunjukkan $\mathrm{Ha}=$ diterima, artinya ada hubungan antara pengetahuan dengan keaktifan kader posyandu di wilayah kerja UPT Puskesmas Kejaksan Tahun 2019.

\section{PEMBAHASAN}

\section{Umur}

Distribusi Umur responden yang paling banyak adalah berusia tua yaitu 49 orang $(92,5 \%)$. Umumnya puskesmas biasanya memilih kader yang masih muda karena fisiknya masih kuat, dinamis dan kreatif tetapi usia muda biasanya cepat bosan, kurang berpengalaman, dan kurang tanggung jawab. Sedangkan kader yang usia tua umumnya fisiknya kurang tetapi bertanggung jawabnya besar, lebih dapat di percaya. Sehingga kader usia tua lebih aktif dalam kegiatan diposyandu maupun di luar kegiatan posyandu.

Umur adalah salah satu faktor penunjang dalam menciptakan kondisi hidup yang sehat. Semakin tinggi usia seseorang semakin banyak pengalaman yang didapat tentang kesehatan. ${ }^{8}$ Umur dapat mempengaruhi motivasi individu karena semakin bertambahnya usia, maka produktivitas akan semakin menurun. Menurut Widiastuti (2006) menjelaskan kader posyandu yang berusia lebih muda tentunya lebih mudah mengajak ibu balita dalam melakukan penimbangan balita karena perbedaan usia dari keduanya yang tidak terlampau jauh atau sebaya.

\section{Pendidikan}

Distribusi pendidikan responden yang paling banyak adalah pendidikan rendah yaitu 27 orang (50,9\%). Seseorang yang menjadi kader secara sukarela mengabdikan dirinya untuk masyarakat, sehingga pendidikan yang dimiliki kader sangat beragam. Masyarakat tidak bisa memilih hanya orang yang berpendidikan tinggi saja yang menjadi kader karena selain bersifat sukarela, orang yang berminat untuk menjadi kaderpun jumlahnya sedikit.

Pendidikan mempengaruhi perilaku pola hidup individu terutama dalam memotivasi untuk berperan serta upaya pembangunan kesehatan dan individu dengan pendidikan yang tinggi lebih mudah memahami informasi dan ada kecenderungan bersikap memperhatikan kesehatan demi peningkatan kualitas hidup.

\section{Pekerjaan}

Distribusi pekerjaan responden yang paling banyak adalah tidak bekerja yaitu 52 orang $(98,1 \%)$. Lingkungan pekerjaan menyebabkan individu memperoleh pengalaman dan pengetahuan baik secara langsung atau tidak langsung. Kader yang memiliki pekerjaan tentunya waktunya tersisa untuk melakukan pekerjaan di rumah atau tempat lain, sehingga semakin sempit kesempatan untuk menjadi kader. Kementerian Kesehatan (2011) menyebutkan hendaknya kader mempunyai waktu 
luang. Kondisi tersebut dimaksudkan, jenis pekerjaan yang akan mempengaruhi keaktifan kader dalam kegiatan posyandu.

Salah satu syarat calon kader adalah wanita yang mempunyai waktu yang cukup untuk melakukan semua tugas kader yang telah ditetapkan, dimana kegiatan posyandu biasanya dilaksanakan pada hari dan jam kerja.

\section{Pengetahuan}

Distribusi pengetahuan responden yang paling banyak adalah pengetahuan tinggi yaitu 29 orang $(54,7 \%)$. Peran serta kader adalah mendidik masyarakat desa melalui penyuluhan, hal tersebut menunjukkan bahwa kader harus mempunyai pengetahuan diatas rata-rata masyarakat desa lainnya. Penyuluhan yang diberikan diharapkan sebagai sarana yang efektif untuk meningkatkan pengetahuan dan menumbuhkan kesadaran masyarakat yang di harapkan terjadinya perubahan perilaku. ${ }^{3}$

Pengetahuan adalah hasil dari tahu dan ini terjadi setelah orang melakukan penginderaan terhadap suatu objek tertentu. Pengetahuan merupakan domain yang sangat penting untuk terbentuknya perilaku seseorang, sehingga pengetahuan kader merupakan salah satu faktor yang penting dalam kesuksesan proses pelaksanaan posyandu. ${ }^{9}$

\section{Hubungan Umur Dengan Keaktifan Kader Posyandu}

Berdasarkan hasil penelitian diperoleh bahwa $\mathrm{P}=0,472(\mathrm{P} \geq \alpha)$ yang bearti tidak ada hubungan yang bermakna antara umur dengan keaktifan kader posyandu yang berada di wilayah kerja Puskesmas Kejaksan Kota Cirebon tahun 2018. Sejalan dengan penelitian Dani Akmalia tentang faktor-faktor yang berhubungan dengan keaktifan kader posyandu di wilayah kerja Puskesmas Nelayan Kota cirebon tahun 2013 bahwa tidak ada hubungan umur dengan keaktifan kader dan Nurfitriani tentang faktor-faktor yang mempengaruhi keaktifan kader posyandu di Puskesmas Tanete Kecamatan Bulukumpa Kabupaten Bulukumpa Tahun 2010 bahwa tidak ada hubungan umur dengan keaktifan kader posyandu.

Umur adalah salah satu faktor penunjang dalam menciptakan kondisi hidup sehat. Semakin tinggi usia seseorang semakin banyak pengalaman yang didapat tentang kesehatan. Semakin tua semakin banyak pengalaman dan pengetahuannya semakin luas, kearifannya semakin mantap dalam pengambilan keputusan dan tindakan.

\section{Hubungan Pekerjaan dengan Keaktifan Kader Posyandu}

Dari hasil penelitian menunjukkan $\mathrm{P}=1,000(\mathrm{P} \geq \alpha)$ yang berarti tidak ada hubungan yang bermakna antara pekerjaan dengan keaktifan kader di posyandu yang berada di wilayah kerja Puskesmas Kejaksan Kota Cirebon tahun 2019. Sejalan dengan penelitian Adisti A.Rumayar tentang faktor-faktor yang berhubungan dengan keaktifan kader posyandu di Kecamatan Langowan Barat Kabupaten Minahasa 2012 bahwa tidak ada hubungan pekerjaan dengan keaktifan kader posyandu dan Dani Akmaliana tentang faktor-faktor yang berhubungan dengan keaktifan kader posyandu di wilayah kerja Puskesmas Nelayan Kota Cirebon tahun 2013 bahwa ada hubungan pekerjaan dengan keaktifan kader. ${ }^{7}$

Lamanya seseorang bekerja dapat berkaitan dengan pengalaman yang didapat ditempat kerjanya. Apabila seorang kader bekerja, maka ia tidak akan mempunyai waktu yang cukup untuk melaksanakan kegiatan posyandu. Salah satu syarat calon kader adalah wanita yang mempunyai waktu yang cukup untuk melakukan semua tugas kader yang telah ditetapkan, dimana kegiatan posyandu biasanya dilaksanakan pada hari dan jam kerja. ${ }^{10}$

\section{Hubungan Pendidikan dengan Keaktifan Kader Posyandu}

Dari hasil penelitian diperoleh $\mathrm{P}=0,132(\mathrm{P} \geq \alpha)$ yang berarti tidak ada hubungan yang bermakna antara tingkat pendidikan dengan keaktifan kader posyandu yang berada di wilayah kerja Puskesmas Kejaksan Kota Cirebon tahun 2019. Sejalan dengan penelitian Dani Akmalia tentang 
faktor-faktor yang berhubungan dengan keaktifan kader posyandu di wilayah kerja Puskesmas Nelayan Kota Cirebon tahun 2013 bahwa tidak ada hubungan pendidikan dengan keaktifan kader posyandu.

Tingkat pendidikan merupakan dasar dalam pengembangan wawasan serta sarana untuk memudahkan bagi seseorang untuk menerima pengetahuan, sikap dan perilaku yang baru. Tingkat pendidikan merupakan dasar pengembangan daya nalar seseorang untuk menerima motivasi. Latar belakang pendidikan seseorang berpengaruh pada beberapa kategori kompetensi dimana semakin tinggi pendidikan seseorang semakin tinggi pula tingkat keterampilan dalam hubungan interpersonal serta semakin tinggi tingkat pendidikan yang didapat seseorang, maka besar keinginan untuk memanfaatkan pengetahuan dan keterampilan.

\section{Hubungan Pengetahuan dengan Keaktifan Kader Posyandu}

Dari hasil penelitian diperoleh bahwa $\mathrm{P}=0,00(\mathrm{P} \leq \alpha)$ yang berarti ada hubungan yang bermakna antara pengetahuan dengan keaktifan kader posyandu yang berada di wilayah kerja Puskesmas Kejaksan Kota Cirebon tahun 2019. Sejalan dengan penelitian Nurfitriani tentang faktor-faktor yang mempengaruhi keaktifan kader posyandu di Puskesmas Tanete Kecamatan Bulukumpa Kabupaten Bulukumpa Tahun 2010 bahwa ada hubungan pengetahuan dengan keaktifan kader posyandu dan Dani Akmalia tentang faktor-faktor yang berhubungan dengan keaktifan kader posyandu di wilayah kerja Puskesmas Nelayan Kota Cirebon tahun 2013 bahwa ada hubungan pengetahuan dengan keaktifan kader. ${ }^{7}$

Pengetahuan merupakan tahap awal seseorang berbuat sesuatu dan pengetahuan tentang apa yang akan dilakukan membuat seseorang mengetahui langkah selanjutnya yang harus diperbuat. Seperti halnya seorang kader posyandu yang harus mengetahui tentang tugas yang diembannya sehingga dapat memberikan pelayanan maksimal kepada masyarakat dalam mengelola posyandu.

Tingkat pengetahuan kader terhadap kesehatan khususnya mengenai pelaksanaan posyandu akan mempengaruhi pola perilaku kader untuk lebih aktif berperan serta dan lebih tanggap untuk setiap permasalahan kesehatan yang terjadi.

\section{SIMPULAN}

Berdasarkan hasil penelitian dapat disimpulkan bahwa:

1. Diketahui hasil umur kader yang paling banyak adalah berusia tua yaitu 49 orang $(92,5 \%)$, pekerjaan paling banyak adalah tidak bekerja yaitu 52 orang $(98,1 \%)$, pendidikan paling banyak adalah pendidikan rendah yaitu 27 orang $(50,9 \%)$, dan pengetahuan paling bnayak adalah pengetahuan tinggi yaitu 29 orang $(54,7 \%)$.

2. Tidak ada hubungan antara umur dengan keaktifan kader posyandu di wilayah kerja UPT Puskesmas Kejaksan Kota Cirebon tahun 2019.

3. Tidak ada hubungan antara pendidikan dengan keaktifan kader posyandu di wilayah kerja UPT Puskesmas Kejaksan Kota Cirebon tahun 2019.

4. Tidak ada hubungan antara pekerjaan dengan keaktifan kader posyandu di wilayah kerja UPT Puskesmas Kejaksan Kota Cirebon tahun 2019.

5. Ada hubungan antara pengetahuan dengan keaktifan kader posyandu di wilayah kerja UPT Puskesmas Kejaksan Kota Cirebon tahun 2019.

\section{SARAN}

1. Untuk Dinas Kesehatan

Mengadakan pelatihan dan pembinaan secara rutin mengenai posyandu, tentang tugas pokok dan fungsi kader posyandu.

2. Untuk Puskesmas

1) Memberikan penyuluhan kepada kader yang berpendidikan rendah dan tinggi, kader baru dengan cara memberikan informasi dan meningkatkan pengetahuan kader yang dapat 
dilaksanakan dalam kegiatan baik formal maupun informal, contoh kegiatan formal adalah saat melaksanakan kegiatan posyandu dan refreshing kader, sedangkan informalnya adalah saat kegiatan diluar posyandu, saat berkumpul kader dan kegiatan lainnya.

2) Meningkatkan edukasi kres club prokesa.

3) Mengadakan inovasi berupa pemberian reward atau sertifikasi penghargaan sebagai kader aktif agar meningkatkan motivasi kader yang tidak aktif menjadi kembali aktif

3. Untuk Masyarakat

1) Harus lebih aktif ikut serta memberikan kontribusi saat dilaksanakan kegiatan posyandu meskipun bukan anggota kader posyandu membantu kader posyandu baik sebelum, pada saat hari pelaksanaan posyandu maupun hari diluar kegiatan posyandu.

2) Membantu tugas-tugas kader yang lainnya selain melaksanakan kegiatan posyandu.

4. Untuk Kader Posyandu

1) Diharapkan untuk lebih meningkatkan keaktifan dalam menjalankan tugas sebagai kader posyandu.

2) Meningkatkan pengetahuan mengenai tugas pokok dan fungsi sebagai seorang kader posyandu dengan cara membaca buku panduan kader posyandu dan mengikuti pelatihan yang diberikan oleh petugas.

\section{DAFTAR PUSTAKA}

1. Kementerian Kesehatan Republik Indonesia bekerja sama dengan POKJANAL Pusat 2012. Modul pelatihan kader Posyandu.[Diakses tanggal 30 Mei 2018]. Tersedia dari: http//ask.ac.id/

2. Kementerian Kesehatan Republik Indonesia. Buku panduan kader Posyandu. Jakarta: Kemenkes RI:2011

3. Puskesmas Kejaksan, Laporan Tahunan Puskesmas Kejaksan Kota Cirebon Tahun 2018: Cirebon. 2019

4. Depkes RI. Pedoman pelaksanaan: program pelayanan kesehatan Puskesmas. [Diakses 30 Mei 2018]. Diunduh dari: http//nsrirye. Ampl.or.id/faktor-faktor yang berhubungan dengan kader.

5. Gemari. Maksimal TP PKK untuk kelola Posyandu. Majalah Keluarga Mandiri 2005.

6. Bapernas. "Assesment kapasitas lokal”. [Diakses tanggal 28 Mei 2018]. Tersedia dari: http//www.issdp.ampl.or.id.

7. Dani Akmalia, faktor-faktor yang berhubungan dengan keaktifan kader posyandu di wilayah kerja UPTD Puskesmas Nelayan Kota Cirebon tahun 2013. Skripsi.Cirebon: fakultas Kesehatan Masyarakat Stikes Cirebon. 2013

8. Sciortino, Rosalina. Menuju kesehatan madani. Penerbit Pustaka Pelajar: Yogyakarta; 2000

9. Wawan A, Dewi M. Teori dan pengukuran pengetahuan, sikap, dan perilaku manusia. Yogyakarta: Nuha Medika;2011.

10. Departemen Kesehatan RI. Buku pedoman umum pengelolaan posyandu tahun 2016. Jakarta: Depkes RI; 2016 